\title{
Tissue Part
}

National Cancer Institute

\section{Source}

National Cancer Institute. Tissue Part. NCI Thesaurus. Code C38625.

Any component of the anatomical structure consisting of similarly specialized cells and intercellular matrix, aggreg ated according to genetically determined spatial relationships, performing a specific function. 